\title{
PENERAPAN METODE DESIGN THINKING PADA MODEL PERANCANGAN ANIMASI PERIKLANAN DIGITAL PENCEGAHAN COVID-19
}

\author{
Camila Zahra Alrazi ${ }^{1}$ \\ Anung Rachman ${ }^{2}$
}

Diterima Agustus. 27, 2021; Disetujui November. 11, 2021

\begin{abstract}
Abstrak: Sejak awal ditemukannya wabah COVID-19 di Indonesia, pemerintah telah melakukan berbagai upaya dalam rangka mencegah penyebaran COVID-19 diantaranya membuat beberapa kebijakan baru dengan upaya preventif dan upaya reaktif. Salah satu upaya preventif yang dilakukan oleh pemerintah adalah dengan menggunakan imbauan yang berisi promosi pencegahan penyebaran COVID-19. Pemerintah dibantu oleh kalangan masyarakat sering memberikan imbauan kampanye pencegahan penyebaran COVID-19, salah satunya adalah penggunaan media animasi digital. Media ini yang banyak ditemukan dalam situs-situs umum sehingga mempermudah penyampaian kepada masyarakat yang meluas. Perancangan yang digunakan menggunakan metode design thinking yang terdiri dari tahapan empathize, define, ideate, prototype dan test. Penggunaan metode design thinking diharapkan dapat digunakan secara efektif untuk merancang animasi digital sehingga promosi pencegahan penyebaran virus COVID-19 dapat menjadi lebih terstruktur dan sistematis. Iklan layanan masyarakat tentang Covid19 di Indonesia dengan menggunakan design thinking dan iklan web berbasis mobile sangat berpengaruh terhadap perspektif masyarakat mengenai kondisi Covid-19 di Indonesia saat ini karena dapat mengedukasi dan menginformasikan kepada masyarakat. Hasil dari perancangan ini memberikan rekomendasi berupa model animasi digital promosi sebagai layanan masyarakat untuk pencegahan virus Covid-19 dengan menggunakan aplikasi Google Web Designer. Menggunakan dasar tersebut dapat disimpulkan metode design thinking memungkinkan desainer dalam pengumpulan berbagai informasi mengenai permasalahan yang ada sehingga mampu mengembangkan gagasan serta membuat alternatif desain dalam berinovasi.
\end{abstract}

Kata Kunci: perancangan; animasi digital; COVID-19; design thinking

${ }^{1}$ Camila Zahra Alrazi is a student at Visual Communication Design, Institut Seni Indonesia Surakarta.

${ }^{2}$ Anung Rachman is a lecturer at Visual Communication Design, Institut Seni Indonesia Surakarta. e-mail : camilaalrazi@gmail.com

e-mail: anung@isi-ska.ac.id 


\begin{abstract}
When COVID-19 pandemics first spread in Indonesia, the government has taken several measures to contain further spread of COVID-19 pandemic by taking some preventive and reactive measures. One of the preventive measures taken by the government is to appeal the public by promoting preventive approach to contain the spread of COVID-19. The government in collaboration with the community has often given campaign appeals to prevent the spread of COVID-19, to use digital animated advertisements. This media are often found in public sites can facilitate delivery to the wider community. This design uses design thinking method which consists of these steps: empathize, define, ideate, prototype and test. The use of the design thinking method is expected to be used effectively to design digital animations so that the promotion of preventing the spread of the COVID-19 virus can be more structured and systematic. Public service advertisements about Covid-19 in Indonesia using design thinking and mobile-based web ads are very influential on people's perspectives regarding the current condition of Covid-19 in Indonesia because they can educate and provide information to the public. The result of this design provide recommendations in the form of digital animation model as a public service for the prevention of the Covid-19 virus by using the Google Web Designer application. With this basis, designers can acquire a design thinking method that allows designers to gather various information about existing problems so that they are able to develop ideas and create design alternatives in terms of design.
\end{abstract}

Keywords: design; digital animation; COVID-19; design thinking

\section{Pendahuluan}

Iklan yang menggunakan animasi cenderung menghasilkan daya ingat tinggi, sikap positif terhadap iklan dan menarik perhatian konsumen dibandingkan iklan statis, serta bertujuan untuk menyampaikan imbauan yang sifatnya informatif, atau memuat promosi terkait suatu produk atau jasa. Animasi sebagai alat komunikasi dan promosi mempunyai peranan penting dalam menginformasikan sesuatu kepada masyarakat, hal ini dinilai sangat komunikatif dan efektif disaat mobilitas manusia yang semakin tinggi sehingga dibutuhkan bentuk media komunikasi dan promosi yang menarik dan interaktif kepada masyarakat (Sunarya et al., 2015, p. 27)

Animasi Periklanan dapat dikenal sebagai bentuk promosi iklan yang fleksibel. Animasi Periklanan dapat dikategorikan sebagai media periklanan yang mobil- itasnya sangat luas sehingga jangkaun terhadap audiens akan semakin besar. Penggunaan Animasi Periklanan sebagai salah satu media alat komunikasi, khususnya untuk melakukan promosi dari bidang sosial hingga kesehatan oleh masyarakat Indonesia. Setiap iklan selalu menggunakan unsur verbal dan visual. Penggunaan komunikasi pada Animasi Periklanan ini berupa tulisan serta gambar visual. Perancangan iklan dan penampilannya dibuat dengan semenarik mungkin agar dapat tersampaikan tujuan oleh pembuat kepada audiens. Penggunaan bahasa iklan yang bersifat persuasif, pendek, solid, dan jelas dapat memberikan pengaruh terhadap pembaca. Penggunaan ilustrasi, logo dan warna dapat mendukung iklan agar lebih menarik.

Indonesia sedang mengalami masa pandemi dari virus COVID-19. Berbagai upaya telah dilaksanakan pemerintah pusat dan daerah untuk menyegerakan masa 
pandemi, salah satunya dengan membuat iklan kampanye tentang COVID-19. Pemerintah dibantu oleh kalangan masyarakat sering memberikan imbauan kampanye pencegahan penyebaran COVID-19 sejak awal munculnya wabah di Indonesia yakni pada bulan Februari 2020 hingga awal bulan Agustus 2021 jumlah kasus COVID-19 di Indonesia telah mencapai 3,53 juta kasus terkonfirmasi (Repositori Data COVID-19 oleh Pusat Sains dan Teknik Sistem (CSSE) UJH, 2021). Cara pencegahan lain yang bisa dilakukan adalah, menghindari tempat tempat yang sifatnya mendatangkan massa banyak serta tidak melakukan kontak dekat dengan orang dengan membatasi jarak antara 1 - 2 meter (Baharudin dan Rompa, 2020, p.3) Menanggapi hal tersebut pemerintah semakin gencar mensosialisasikan serta mengedukasi masyarakat agar memutus rantai penyebaran virus COVID-19.

Iklan Layanan Masyarakat (ILM) adalah suatu pengumuman ataupun pemberitahuan tanpa ada pungutan biaya demi memajukan suatu aktivitas, program, layanan pemerintah, ataupun aktivitas sosial sebagai layanan organisasi non-profit serta pemberitahuan lainnya yang memiliki manfaat bagi masyarakat (Putri, 2020, p. 11). ILM menyajikan pesan sosial dengan tujuan mendorong atau memotivasi masyarakat untuk tanggap dan peduli terhadap suatu permasalahan tertentu, contohnya ajakan pencegahan penyebaran virus COVID-19.

Penggunaan animasi periklanan sebagai media promosi yang efektif juga telah dibuktikan dalam beberapa penelitian terdahulu. Menurut hasil penelitian yang dilakukan oleh Deuis et al. (2019) tentang efektivitas media promosi menggunakan iklan animasi periklanan dengan metode S-O-R (Stimulus-Organism-Respon) untuk menentukan apakah penggunaan animasi periklanan efektif untuk meningkatkan jumlah persentase respon positif dari iklan animasi Richeese Nabati. Hasil dari penelitian tersebut menunjukkan bahwa nilai persentase produk Richeese Nabati terhadap keputusan pembelian konsumen meningkat secara signifikan dan cukup efektif dalam meninggalkan kesan membekas kepada target audiens.

Perancangan iklan animasi digital terkait promosi pencegahan penyebaran virus COVID-19 dapat bermanfaat membantu upaya pemerintah menanggulangi virus COVID-19. Masyarakat akan memperoleh informasi metode yang dapat dilakukan dalam pencegahan penyebaran virus COVID-19, dan melakukan aksi yang diiklankan dalam animasi digital tersebut. Perancangan iklan dapat dibuat dengan bantuan aplikasi Google Web Designer. Aplikasi Google Web Designer adalah piranti lunak yang memberikan kemudahan untuk membuat suatu desain web modern interaktif tanpa adanya manipulasi desain penggunaan kode CSS. Aplikasi tersebut memberikan kemudahaan dalam perancangan bangun iklan terutama iklan website yang menggunakan berbagai fitur, tampilan kode dan tampilan desain dan easy and workflow. Penggunaan aplikasi dalam pembuatan iklan web dapat menghasilan iklan dalam tampilan seluler dan PC dengan pembuatan materi iklan HTML5 dan iklan AMPHTML.

Adanya perkembangan revolusi industri 4.0 membuat perubahan penting dalam memberikan informasi tambahan bagi masyarakat tentang kecakapan teknologi dan informasi. Hal ini beriringan dengan perkembangan teknologi yang harus diimbangi dengan keterampilan SDM dalam mengelola informasi (Firmansyah and Sari, 2019). Perancangan ini menggunakan metode pendekatan design thinking yang terdiri dari 5 tahapan, yaitu empathize, define, ideate, prototype, dan test. Menurut penelitian Aman et al. (2020), design thinking menjadi konsep berpikir dalam menemukan ide yang mulai digemari oleh banyak orang dalam waktu be- 
berapa tahun ini. Design thinking sangat esensial dengan manusia sebagai pusat proses inovasi yang menekankan pada observation, collaboration, fast learning, visualization of ideas, rapid concept prototyping.

Menurut penelitian Tohiroh (2021), iklan layanan masyarakat tentang Covid19 di Indonesia dengan menggunakan design thinking dan iklan web berbasis mobile sangat berpengaruh terhadap perspektif masyarakat mengenai kondisi Covid-19 di Indonesia saat ini karena dapat mengedukasi dan menginformasikan kepada masyarakat. Informasi yang valid mengenai Covid-19 akan semakin membuka mata dan perspektif masyarakat terhadap setiap tindakan yang akan dilakukan. Sehingga akan semakin menekan penyebaran Covid-19 ini. Tujuan makalah ini adalah membuat model perancangan animasi digital pencegahan COVID-19 dengan menggunakan aplikasi Google Web Designer dengan metode design thinking.

\section{Metode Penelitian}

Penelitian ini merupakan penelitian jenis kualitatif dalam rangka menggambarkan perancangan iklan animasi digital terkait pencegahan penyebaran COVID-19. Moleong (2014) mendefinisikan penelitian kualitatif sebagai sebuah penelitian yang tujuan utamanya adalah untuk memahami permasalahan-permasalahan sosial dan manusia secara lebih lanjut atau mendalam. Menurut Gunawan (2015), penelitian kualitatif yang menjadi penekanan penelitian adalah analisis proses dari kerangka berpikir dengan teknik induksi yang erat kaitannya dengan dinamika relasi antar fenomena yang menjadi pengamatan penelitian dengan menerapkan logika ilmiah.

Penulis menggunakan pendekatan kualitatif deskriptif dengan metode eksploratif, yaitu metode yang berupaya
Penerapan Metode Design Thinking Pada Model Perancangan Animasi Periklanan Digital Pencegahan

Covid-19

menggambarkan atau mencari tahu apa yang terjadi lewat pertanyaan-pertanyaan $5 \mathrm{~W}+1 \mathrm{H}$ atau pertanyaan lain serupa yang memiliki hubungan dengan karakteristik fenomena yang diamati baik dalam jenis ukuran, bentuk, pola, hingga distribusi. Kelebihan dari penelitian ini adalah penulis turut menggunakan pendekatan dan proses design thinking dalam mengumpulkan informasi yang melibatkan pengguna (Daalsgard, 2014, p. 148).

Metode yang digunakan dalam melakukan perancangan adalah metode "design thinking", metode ini dikenal sebagai suatu proses berpikir komprehensif yang berkonsentrasi untuk menciptakan solusi yang diawali dengan proses empati terhadap suatu kebutuhan tertentu yang berpusat pada manusia (human centered) menuju suatu inovasi berkelanjutan berdasarkan kebutuhan penggunanya (Razi et al., 2020). Metode design thinking berfokus terhadap pemecahan masalah dengan menyeimbangkan otak kanan yang cenderung tidak simetris dan otak kiri yang cenderung linear, terstruktur, dan sistematis (Miller, 2017). Keunggulan metode design thinking adalah mampu memicu berbagai ide inovatif seseorang ketika berada pada fase inspirasi, ide, serta implementasi terkait setiap siklus lebih dari sekali yakni ketika sedang melaksanakan pengembangan berbagai ide baru serta sedang melakukan eksplorasi berbagai solusi baru. Penggunaan metode ini dapat dilakukan pengulangan dari langkah serta proses untuk pengembangan hingga tercapainya solusi serta desain yang tepat. Tahapan dari metode design thinking ada 5 seperti yang ditampilkan pada gambar 1 .

\section{Tahap Empathize}

Emphathize merupakan tahap paling mendasar dari proses design thinking bertujuan untuk memetakan sudut pandang dari subjek yang ingin dituju atau target dari sebuah desain yang diciptakan. Se- 


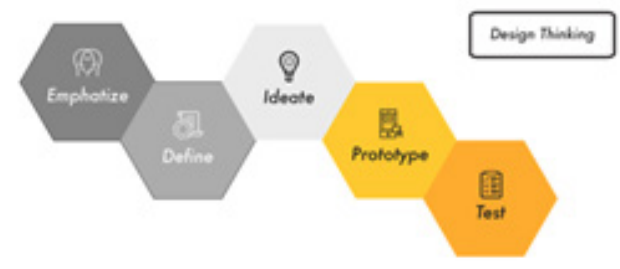

Gambar 1. Lima Tahapan Metode Design Thinking (Sumber: Plattner, 2010)

bagai seseorang yang menentukan desain, pemetaan berdasarkan empati dibutuhkan dalam menganalisa permasalahanpermasalahan dan hal-hal yang bermakna bagi penerima manfaat sehingga dapat diterima dengan baik. Oleh karena itu, dalam proses empathize sendiri terdapat tiga proses yang harus dilalui, yakni observe, engage, dan immerse (Vianna, 2011). Empathize (empati) merupakan sebuah inti proses karena permasalahan yang timbul harus diselesaikan dengan cara berpusat kepada manusia, metode ini berupaya untuk memahami permasalahan yang dialami pengguna supaya kita dapat merasakan dan mencari solusi untuk permasalahan tersebut (Sari et al., 2020)

Observe yaitu peneliti melihat pengguna dan perilaku mereka dalam menggunakan produk (poster) dalam hal ini, observe menitikberatkan pengamatan pada interaksi serta reaksi target pemasaran terhadap berbagai hal yang terjadi di sekitar mereka. Timbulnya pemahaman atas reaksi dan interaksi masyarakat akan menimbulkan ide atau inovasi yang dapat dipahami dan relevan kepada kehidupan masyarakat sehingga mempengaruhi sentimen target masyarakat secara positif. Engage yaitu berinteraksi dan melakukan interview kepada pengguna terkait kebutuhan dan harapan. Terjadinya pertukaran opini atau pun ide yang diakibatkan oleh proses engaging ini akan memberikan pendesain pemahaman lebih jauh mengenai pemikiran, kepercayaan, dan nilai yang tengah berkembang pada masyarakat yang dituju sehingga dapat mem- inimalisir perbedaan interpretasi informasi serta antisipasi hal-hal yang dapat mereduksi makna iklan. Immerse yaitu mencoba untuk mengalami atau rasakan apa pelanggan alami atau rasakan (Saputra, 2016).

Penulis dalam tahapan ini, mengumpulkan berbagai informasi relevan terhadap penyebaran virus COVID-19 melalui studi literatur berbasis pada bidang kesehatan, serta mengamati berbagai opini-opini mengenai vaksinasi COVID-19 yang berkembang pada masyarakat sehingga informasi yang didapat mengenai COVID-19 dapat di- pertanggungjawabkan, akurat, dan relevan dengan turut mempertimbangkan kondisi masyarakat. Melalui tahapan ini informasi yang disampaikan dapat dipahami dan diterima dengan baik oleh masyarakat.

\section{Tahap Define}

Hasil dari data yang terkumpul pada tahap pertama dijabarkan lalu dikerucutkan sehingga dapat terfokus pada satu permasalahan atau satu isu. Penentuan fokus dari sebuah desain merupakan penentuan dari ide utama dari keseluruhan desain serta penentuan ruang lingkup dari keseluruhan desain tersebut. Pembentukan dari ide utama dari sebuah desain harus mempertimbangkan berbagai hal yang telah diamati dalam proses sebelumnya karena mencerminkan hal-hal yang didapatkan pada proses empathize.

Desainer dalam memecahkan masalah harus mampu untuk menguraikan fokus pada target yang spesifik, semisal penargetan berdasarkan kelompok usia atau masyarakat dengan pendapatan tinggi. Setelah desainer mampu untuk menentukan rentang target yang dituju, desainer bergerak berdasarkan insight dan kebutuhan-kebutuhan yang diutarakan atau dapat ditemui pada masyarakat (Batmetan, 2018, p. 27). Iklan ini ditujukan untuk masyarakat Indonesia usia 15 sampai 50 an. Masyarakat usia tersebut 
merupakan usia yang memiliki kemungkinan membuka sosial media atau website, selain itu usia remaja sampai tua dapat mencerna pesan dengan lebih baik. Menggambarkan permasalahan yang ditemui pada tahap empathize dan mempersempit ruang lingkup pembahasan akan menciptakan kecenderungan untuk memicu ideide solutif yang lebih berkualitas, tepat sasaran, dan mendalam.

Dalam tahap ini penulis membongkar dan mensintesis temuan dari tahap empati dan memberikan wawasan yang bermakna dengan sudut pandang yang berasal dari pengguna. Penulis akan memberikan deskripsi kebutuhan konsumen yang ditemukan dan melihat pandangan konsumen terhadap produk subjek penelitian. Objektif utama dari dilaksanakannya proses ini ialah merepresentasikan perspektif (point of view) dari desainer secara fisik dari permasalahan- permasalahan atau pandangan yang didapat melalui analisis data. Penulis dalam proses ini melakukan pengerucutan berbagai informasi yang diterima sehingga dapat memproduksi berbagai ide yang diharapkan mampu merangkum permasalahan serta solusi pencegahan penyebaran COVID-19 dengan tepat.

\section{Tahap Ideate}

Tahapan selanjutnya merupakan sebuah fase yang melibatkan berbagai pihak-pihak terkait dalam prosesnya dengan brainstorming atau pertukaran pikiran yang kemudian dimanifestasikan melalui mind-map, pembuatan sketsa, atau prototipe sederhana (Baskoro \& Bayyinah, 2020, p. 85). Tahapan ini menekankan pada ide-ide yang dapat dibuat atau dikembangkan melalui konsep-konsep yang telah dijabarkan pada proses sebelumnya sehingga menciptakan suatu gagasan atau solusi yang kuat, berkesan, dan mudah untuk disebarkan atau dimengerti oleh masyarakat. Dalam proses ideate memiliki keragaman dalam ide bukan-
Penerapan Metode Design Thinking Pada Model Perancangan Animasi Periklanan Digital Pencegahan

Covid-19

lah suatu masalah dikarenakan proses ini lebih menekankan dalam pembuatan ide yang beragam dan dapat direalisasikan, sementara untuk menentukan ide terbaik di antara semua pilihan-pilihan gagasan tersebut terhadap masyarakat akan dibuktikan secara empiris melalui tahapan test.

Penggunaan data dalam penelitian ini berasal dari tahap sebelumnya yang akan diproses supaya menghasilkan berbagai ide serta gagasan yang tertampung hingga didapati temuan berupa solusi dari pemecahan permasalahan pencegahan penyebaran virus COVID-19. Seluruh ide yang muncul dan tertampung akan dilaksanakan pengujian, pengolahan atau perbandingan secara kreatif hingga menemukan pilihan berupa ide terbaik yang selanjutnya akan digunakan dalam penyelesaian masalah pencegahan penyebaran virus COVID-19.

\section{Tahap Prototype}

Prototype atau mode prototipe merupakan proses repetitif dari pengembangan model yang sebelumnya telah dirumuskan dalam bentuk gagasan atau ide-ide dalam bentuk atau tampilan yang mendekati dengan hasil final. Secara singkat, prototipe dapat dimaknai sebagai aplikasi ide-ide yang telah didapatkan dari proses sebelumnya. Tahap prototype berfokus pada persiapan sebelum memasuki tahap tes di mana prototipe akan berinteraksi langsung dengan user, sehingga tahap ini merupakan tahap yang bersifat lebih kepada permasalahan teknis (Sutrisno et al., 2018, p. 106).

Terdapat beberapa hal yang didapatkan melalui tahap prototype, yakni mengevaluasi adanya kesalahan atau kecacatan desain pada proses eksekusi; mengatasi berbagai permasalahan yang kemungkinan timbul setelah adanya bentuk fisik dari ide-ide tersebut; untuk memprediksi adanya kegagalan dan menghindari kerugian yang lebih besar 
setelah adanya finalisasi produk; untuk melihat berbagai posibilitas yang mungkin terjadi setelah desain diluncurkan. Adanya proses ini, kita akan dengan mudah dapat menentukan langkah selanjutnya yang akan diambil dan memperbaiki masalah tanpa perlu berlarut-larut dan berfokus pada masalah-masalah yang dianggap tidak penting. Hal ini bertujuan apabila terdapat kekurangan atau masalah perbaikan dilakukan secara berulang-ulang hingga menghasilkan prototype yang terbaik.

Perlu memperhatikan beberapa hal dalam pembuatan prototype agar hasil menjadi maksimal. Pertama pilih tools berdasarkan kebutuhan. Kedua, bagi beberapa komponen agar lebih mudah dan lebih fokus. Ketiga, satukan komponen-komponen agar menjadi satu alur. Terakhir lakukan validasi kepada user (Tohiroh, 2021). Iklan AMPHTML hanya dapat ditayangkan setelah divalidasi dalam pencegahan desain atau creative yang rusak atau tidak bisa bekerja dengan baik saat ditayangkan. Validasi ini dapat dilakukan dengan interview dan voting. Beberapa langkah berikut dilakukan pada metode ini : type

a. Pengguna akan diberikan proto-

b. Pengguna akan memberikan feedback pada prototype

c. Feedback ini berisi tentang kesesuaian prototype dengan keinginan user serta apakah telah memenuhi kaidah consistency, hierarchy, personality, layout, type, color, imagery, control dan affordances.

d. Peneliti merangkum seluruh feedback dari user sehingga menghasilkan kesimpulan. Kesimpulan ini nantinya akan menghasilkan prototype final apakah layak ditayangkan atau tidak.

5. Tahap Test
Tahap test merupakan tahapan terakhir dari proses design thinking di mana produk akan diuji dan dievaluasi langsung oleh pihak user atau masyarakat. Proses ini ditandai dengan adanya interaksi di antara pengguna dan pengembang (desainer). Proses ini dilakukan dengan menyertakan berbagai laman interaktif, kuesioner, atau data lain sebagai pengujian dan evaluasi produk kepada masyarakat. Dari percobaan tersebut akan muncul umpan balik yang diberikan oleh pengguna dan dilakukan penyempurnaan atas kekurangan dan ketidaksempurnaan dalam suatu produk. Tahap ini menjadi peluang untuk memperbaiki solusi serta membuat produk menjadi lebih baik lagi (Wibowo et al., 2020, p. 4). Secara menyeluruh, tahap ini juga mampu memprediksi ketahanan produk atau desain.

Penelitian ini menggunakan data primer dan data sekunder. Menurut Sugiyono (2014), data primer merupakan data atau informasi yang diperoleh secara langsung dengan tujuan untuk menjawab permasalahan penelitian. Data primer ini diperoleh melalui observasi terkait langkah-langkah yang harus dipersiapkan dalam proses design thinking untuk merancang iklan animasi digital terkait dengan pencegahan penyebaran COVID-19. Sedangkan data sekunder mengacu pada informasi yang telah tersedia sebelumnya, yang diperoleh penulis secara tidak langsung, yang didapat dari jurnal penelitian terdahulu, studi Pustaka, literatur-literatur pendukung dan internet, perancangan iklan animasi digital ini penulis menggunakan teknik AMPHTML. Iklan animasi digital berbasis AMPHTML ini pun sudah termasuk popular dalam bidang periklanan digital dikarenakan tekniknya yang lebih cepat, ringan dan aman.

Solusi yang telah dinyatakan valid diimplementasikan ke dalam format dan platform media yang sesuai. Tahap ini merupakan tahap akhir pengemasan 
produk menjadi konten HTML5. Tahap ini merupakan kemampuan produk akhir dalam menyampaikan makna melalui animasi. Aspek animasi dari desain iklan digital menjadi kerangka utama untuk kebutuhan saat penayangan iklan (konsep); kondisi-situasi dan trend saat iklan disajikan (konteks), serta teknik penyajian iklan (konten). Iklan layanan masyarakat bertahan melawan pandemi COVID-19 adalah iklan layanan masyarakat yang memiliki fungsi sebagai Informing atau pemberitahuan program dan kegiatan dari pemerintah pada masyarakat. Persuading atau usaha untuk meyakinkan masyarakat agar bisa ikut dalam program, layanan, kegiatan atau aktivitas pemerintah. Reminding atau mengingatkan program, layanan, kegiatan atau aktivitas yang dilakukan pemerintah. Mengenai protokol kesehatan dan pola hidup sehat di saat pandemi COVID-19 (Ulum et al., 2021).

\section{Hasil dan Pembahasan}

Pelaksanaan perancangan memiliki fokus pada media iklan animasi digital yang letaknya berada di situs-situs publik yang terjangkau masyarakat. Berdasarkan metode design thinking, penulis mencoba memaparkannya dalam kerangka alur metode sehingga didapatkan hasil perancangan yang dapat mengatasi permasalahan utama dalam penelitian ini diperoleh 5 poin penting antara lain:

\section{Tahap Empathize}

Tahapan Empathize telah diperoleh data permasalahan terkait penyebaran virus COVID-19. Beberapa kesimpulan tentang perolehan data, yaitu, virus COVID-19 dapat menular melalui droplet. Hal yang dapat dilakukan untuk mencegah penularan yakni 5M: 1) Memakai masker; 2) Mencuci tangan; 3) Menjaga Jarak; 4) Menghindari kerumunan; 5) Membatasi mobilitas. Salah satu upaya pemerintah
Penerapan Metode Design Thinking Pada Model Perancangan Animasi Periklanan Digital Pencegahan

Covid-19

yang dilaksanakan untuk mengurangi penyebaran virus COVID-19 ialah dengan menggalakan vaksin gratis bagi seluruh masyarakat Indonesia. Terdapat banyak pemberitaan kasus KIPI (Kejadian Ikutan Pasca Imunisasi) yang menimbulkan keresahan bagi masyarakat sehingga menimbulkan kecenderungan untuk enggan melakukan vaksinasi. Perolehan hasil tersebut dapat digunakan sebagai referensi ataupun acuan dalam pembuatan iklan animasi digital yang akan dirancang sehingga akan menghasilkan sesuai dengan permasalahan terkait serta mampu menyelesaikan permasalahan yang ada.

Menurut penelitian Schalmo et al., (2020), peneliti harus memiliki tingkat empati yang tinggi untuk melihat dunia melalui mata pengguna dan memahami persepsi dan sensasi mereka. Selanjutnya, alasan untuk persepsi tertentu harus dianalisis untuk mengidentifikasi keinginan dan kebutuhan pengguna yang tidak terpenuhi.Informasi ini perlu disajikan kepada beragam masyarakat dan HCP untuk berbagi dengan pasien, perawat mereka, dan masyarakat umum. Proses mempelajari keterampilan baru dan memperbaharui pengetahuan medis untuk memberikan perawatan yang aman dan efektif.

\section{Tahap Define}

Permasalahan yang sedang dihadapi dalam kasus pencegahan penyebaran virus COVID-19 sesuai pada tahap empathize diselesaikan melalui promosi menggunakan media iklan animasi digital. Hasil perolehan data di lapangan yakni terjadi peningkatan jumlah kasus terkonfirmasi positif COVID-19 dan saat ini Indonesia sedang mengalami gelombang ke-2 lonjakan kasus COVID-19. Adanya KIPI dari kegiatan vaksin COVID-19 membuat masyarakat khawatir, disertai masih banyaknya masyarakat yang enggan melaksanakan pencegahan penyebaran COVID-19 sesuai protokol 5M. 
Sasaran dari media iklan animasi digital yakni masyarakat Indonesia terutama yang belum melakukan vaksin dan belum berperilaku protokol $5 \mathrm{M}$. Tersebarnya iklan animasi digital terkait promosi pencegahan penyebaran virus COVID-19 secara luas diharapkan mampu mengurangi jumlah kasus positif COVID-19 di Indonesia. Hasil dari pendalaman materi tersebut kemudian akan dibahas lebih lanjut pada tahap berikutnya.

\section{Tahap Ideate}

Pelaksanaan pengumpulan berbagai ide meliputi beragam alternatif desain serta referensi desain poster terkait pencegahan penyebaran virus COVID-19. Penggunaan konsep desain yakni desain menggunakan objek foto. Beberapa gambar alternatif serta referensi dari pembuatan desain tersaji pada Gambar 2.

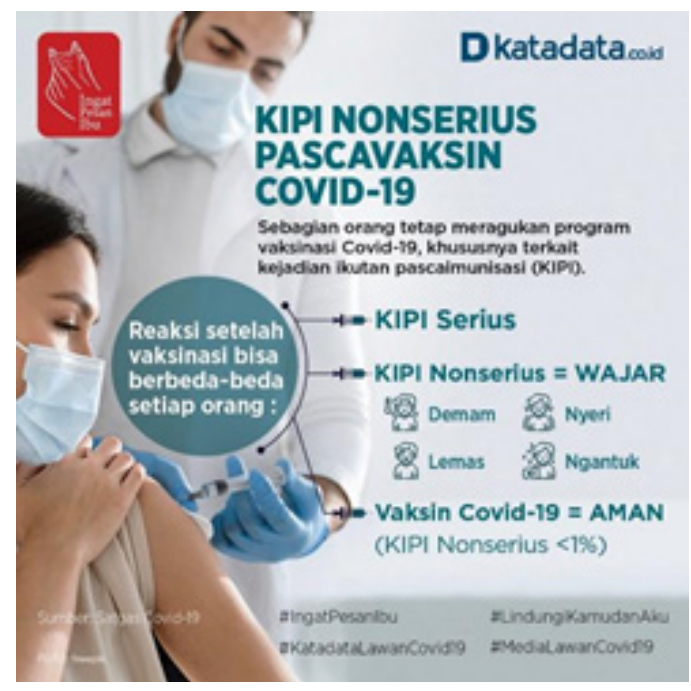

Gambar 2. Alternatif Desain menggunakan Objek Foto (Sumber:https://katadata.co.id/ariemega/infografik/ 6oob85ff7178f/kipi-nonserius-pascavaksin-covid-19)

Contoh alternatif desain yang menggunakan objek foto pada Gambar 2 digunakan di kalangan masyarakat menggunakan objek foto manusia yang nyata dapat memotivasi dan meningkatkan kepercayaan para pemerhatinya sehingga mampu mempengaruhi pencegahan penyebaran virus COVID-19. Menurut Aryanto dan Nyoman (2020), gejala covid-19 yang paling umum adalah demam, batuk kering, dan rasa lelah. Gejala lainnya yang lebih jarang dan mungkin dialami beberapa pasien meliputi rasa nyeri dan sakit, hidung tersumbat, sakit kepala, konjungtivitis, sakit tenggorokan, diare, kehilangan indera rasa atau penciuman, ruam pada kulit, atau perubahan warna jari tangan atau kaki. Gejala-gejala yang dialami biasanya bersifat ringan dan muncul secara bertahap. Untuk mencegah supaya orang lain tidak tertular dan sebaliknya, diwajibkan untuk disiplin jika keluar rumah dengan memakai masker, jaga jarak 1,5 - 2 meter dan hindari konsentrasi massa.

Jenis desain pada gambar 2 dilakukan pertimbangan referensi dengan melihat keselarasan konsep yang diambil untuk perancangan iklan animasi digital dari promosi pencegahan virus COVID-19. Berbagai referensi telah terkumpul pada tahapan ini, selanjutnya dilaksanakan penciptaan sketsa desain sesuai tujuan dalam membantu proses perancangan desain poster iklan animasi digital promosi pencegahan virus COVID 19 yang ada pada gambar 3 .

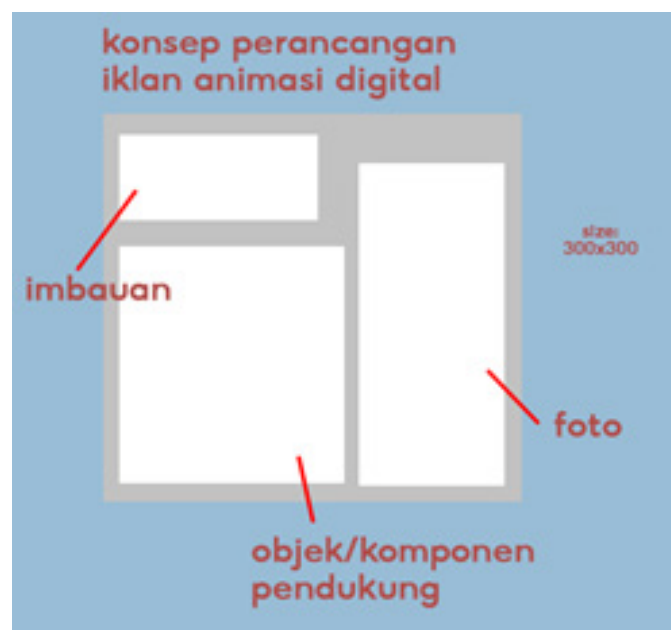

Gambar 3. Konsep Desain dari perancangan iklan animasi digital mengenai promosi pencegahan virus COVID-19 (Sumber : Dokumentasi Penulis, 2021) 


\section{Camila Zahra Alrazi ${ }^{1}$ Anung Rachman ${ }^{2}$}

\section{Tahap Prototype}

Tahapan selanjutnya ialah purwarupa dari referensi dan ide tertampung menjadi suatu desain visual. Penampilan desain visual pada iklan animasi digital berupa digital banner pencegahan penyebaran virus COVID-19 dengan 5M menggunakan flat design, dilanjutkan ajakan pelaksanaan vaksin, serta imbauan terkait KIPI dengan penggunaan objek foto. Pembuatan desain visual ditujukan untuk menyampaikan pesan dan maksud yang sepaham tertangkap bagi pemerhati iklan animasi digital. Perancangan purwarupa dengan dibantu software Google Web Designer format HTML5. Proses pembuatan desain tersaji pada Gambar 5. pembuatan desain menggunakan Google Web Designer.

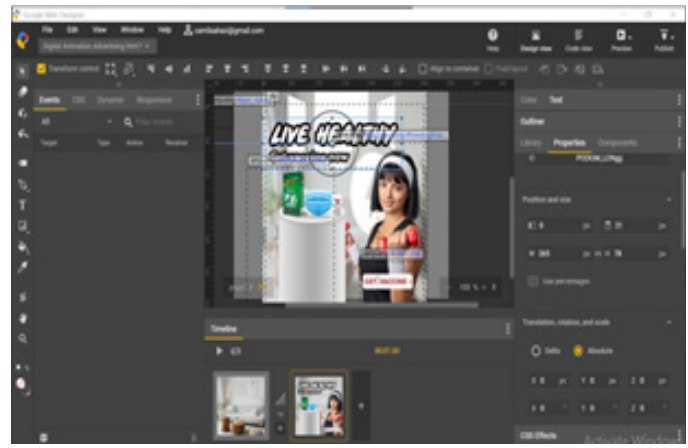

Gambar 4. Proses perancangan berbasis AMPHTML (Sumber: Dokumentasi Penulis, 2021).

Gambar perancangan tersebut menampilkan rancangan animated mini banner dengan gabungan desain objek dengan foto dan ilustrasi flat design. Bagian objek dengan foto manusia dimaksudkan bahwa ajakan untuk melakukan kegiatan serupa yakni menggunakan masker dan memulai gaya hidup lebih sehat. Bagian kanan juga disertai tulisan imbauan untuk melakukan vaksinasi. Selanjutnya pada bagian kanan penggunaan flat design menampilkan masker kesehatan dan juga produk multivitamin. Visual yang disajikan bertujuan agar mudah dipahami oleh pembacanya dan dapat diterapkan dengan baik dengan menggu-
Penerapan Metode Design Thinking

Pada Model Perancangan Animasi Periklanan Digital Pencegahan

Covid-19

nakan gaya visual yang menghibur, minimalis, simpel dan sederhana dapat membuat pesan iklan yang ingin disampaikan lebih cepat terbaca oleh masyarakat, sehingga diharapkan timbul rasa nyaman dan tidak bosan saat melihat iklan layanan masyarakat yang akan dirancang.

Prototype dibuat berdasarkan sketch pada tahap sebelumnya. Adapun langkah-langkah dalam membuat prototype sebagai berikut :

a. Mengamati sketch solution yang telah dibuat sebelumnya dan menentukan komponen apa yang dibutuhkan seperti logo atau icon.

b. Menggunakan tool dalam aplikasi desain Google Web Designer untuk membuat desain komponen yang akan digunakan.

c. Menghimpun komponen untuk kemudian dijadikan satu pada artboard.

d. Mengkaji kembali semua rancangan komponen yang telah dibuat, sehingga prototype yang dihasilkan layak untuk diujikan ke target.

\section{5. $\quad$ Tahap Test}

Tahapan selanjutnya ialah melaksanakan pengujian hasil desain yang sebelumnya telah dikerjakan di Google Web Designer. Tahap ini desainer dapat melakukan tes eksekusi desain yang telah dibuat seperti bagaimana hasil akhir desainnya setelah ditampilkan dari sudut pandang audiens. Prototype yang berbeda disajikan kepada pengguna. Tujuannya adalah untuk mendapatkan pengalaman penting dengan penggunaan prototype. Prototype juga diuji di pasar, tahap ini bertujuan untuk untuk memperbaiki dan mengembangkan prototype lebih lanjut. Secara menyeluruh, tahap ini juga mampu memprediksi ketahanan produk atau desain. Desainer dapat membagikan atau mempublikasikan preview akhir desain seperti ditunjukan pada Gambar 5 . 


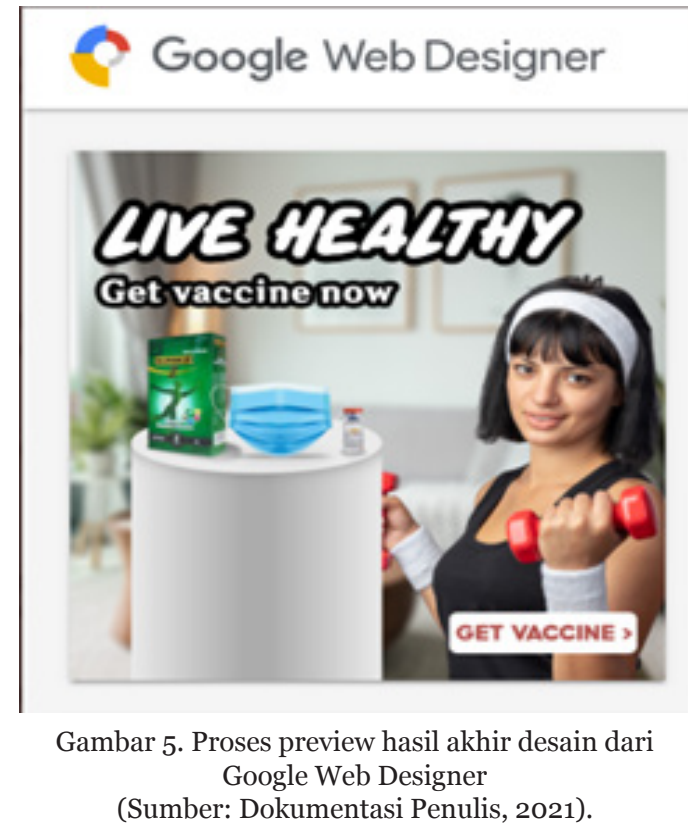

Seperti yang penulis sudah bahas pada awal jurnal, iklan AMPHTML adalah jenis iklan animasi digital yang memerlukan ad validator sebagai penentu apakah iklan tersebut dapat tayang dengan baik di laman situs ketika pertama kali mengakses. Proses perancangan iklan animasi periklanan digital berbasis AMPHTML, iklan tersebut harus memenuhi segala kriteria dalam penayangan. Hal ini bisa dicek saat menggunakan aplikasi Google Web Designer pada jendela ad validator checker yang telah disediakan dari aplikasi ini sendiri.

\section{Kesimpulan}

Dari kajian ini, dapat disimpulkan bahwa iklan animasi digital merupakan salah satu bentuk media ruang yang memiliki beberapa keunggulan yang efektif untuk mencapai sasaran yang ingin dituju. Salah satu kegunaan iklan animasi digital sendiri ialah sebagai salah satu media alat komunikasi yang digunakan untuk promosi dari bidang sosial sampai bidang kesehatan. Di masa pandemi

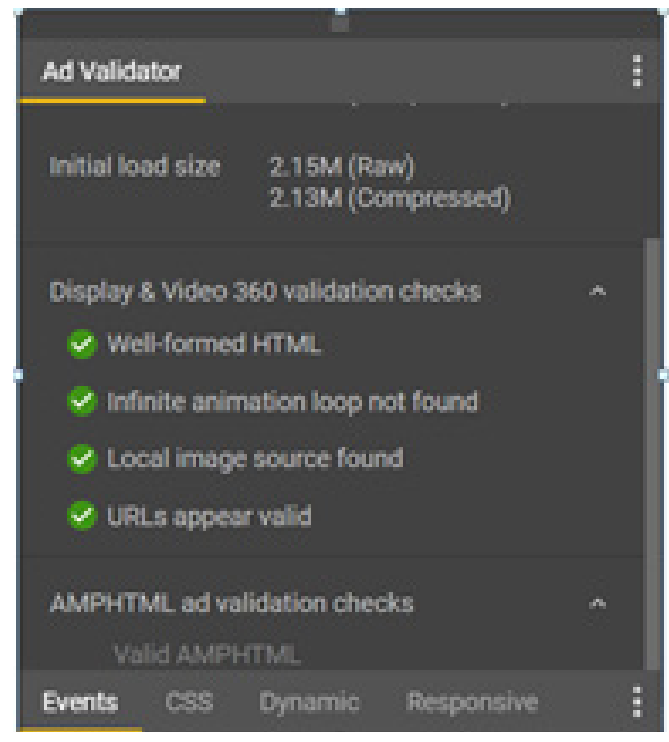

Gambar 6. Jendela ad validator checker dari Google Web Designer

(Sumber: Dokumentasi Penulis, 2021).

ini pemerintah Indonesia menggunakan Iklan animasi digital sebagai iklan kampanye tentang COVID-19, hal ini dikarenakan keberadaan iklan animasi digital dinilai efektif untuk mempengaruhi masyarakat yang melihat iklan tersebut.

Berdasarkan penjabaran tersebut pada iklan layanan masyarakat tentang Covid 19 di Indonesia, dilihat dari analisis dan pembahasan maka dapat penulis simpulkan bahwa kehadiran iklan berbasis google web designer sangat berpengaruh terhadap perspektif masyarakat mengenai kondisi Covid-19 di Indonesia saat ini. Covid-19 yang merupakan virus berbahaya yang dapat menular dengan mudah memang sulit dihentikan, namun dengan adanya iklan layanan masyarakat mengenai covid-19 maka dapat mengedukasi dan menginformasikan kepada masyarakat sehingga akan semakin menekan penyebaran Covid-19 ini.

Berdasarkan penelitian yang dilakukan melalui metode Design thinking maka iklan web ini dilaksanakan melalui tahapan yang panjang. Tahapan ini 
dilakukan dari mengumpulkan informasi mengenai Covid-19 hingga mencapai kesimpulan dan saran untuk melanjutkan penelitian selanjutkan. Perancangan Iklan Layanan Masyarakat (ILM) dengan metode design thinking yang memiliki lima tahapan. Tahap pertama, Empathize, tahap ini merupakan tahapan dimana peneliti mengumpulkan informasi yang relevan terhadap penyebaran virus COVID-19 dari berbagai sumber literatur dalam bidang kesehatan. Tahapan kedua, Define, dalam tahapan ini peneliti akan mengerucutkan informasi yang didapatkan guna mendapatkan rangkuman yang diharapkan menghasilkan rangkuman dari permasalahan dan juga solusi pencegahan penyebaran COVID-19. Tahapan ketiga, Ideate, tahapan ini membutuhkan berbagai pihak untuk melakukan brainstorming yang nantinya bisa dihasilkan ide-ide berupa solusi pencegahan penyebaran virus COVID-19. Kemudian, ideide tersebut disusun menjadi pembuatan sketsa yang nanti berupa referensi desain dan alternatif desain. Tahapan keempat, Prototype, tahapan ini merupakan pengaplikasian dari ide-ide yang telah dihasilkan menjadi suatu desain visual dalam desain. Tahapan kelima, Test, tahapan ini merupakan tahapan terakhir dimana desainer dapat mempublikasi preview akhir desain dan kemudian dapat mendapat umpan balik dari pengguna sehingga dapat dilakukan penyempurnaan sesuai dengan umpan balik yang diterima.

Target yang diharapkan oleh penulis melalui media iklan ini adalah kedepannya masyarakat dapat menerapkan peraturan yang dikeluarkan pemerintah yaitu untuk mengikuti vaksinasi yang berfungsi untuk meningkatkan sistem kekebalan imun. Pentingnya web iklan sangat mudah disebarluaskan sehingga menjadi media yang efektif. Usia ini antara 15 hingga 40 tahun, kelompok usia tersebut merupakan yang masih dapat berpikir lebih bijak serta dapat memahami informasi yang ada.
Penerapan Metode Design Thinking

Pada Model Perancangan Animasi Periklanan Digital Pencegahan

Covid-19

\section{Referensi}

Aman, S., Supriyanto dan M. Anggraeni. Implementasi BMC dengan metode design thinking dalam menghadapi Covid-19 Di Ikm Pati. Jurnal Teknologi Manajemen dan Industri,1(2), pp. 6-14. https://ejr.stikesmuhkudus.ac.id/index.php/jatmi/article/ view/1023/o

Arens, W., \& Weigold, M. (2013). Contemporary Advertising and Integrated Marketing Communications. NewYork: McGraw-Hill.

Aryanto, H \& Nyoman, L. (2020). Pencegahan Covid-19 melalui infografis di fakultas bahasa dan seni Unesa. Jurnal Dimensi, 17(1), pp. 101-111.https:// www.trijurnal.lemlit.trisakti.ac.id/dimensi/article/view/7849/5650

Baharuddin dan Andi Rumpa, Fatimah. (2020). Melindungi Diri Sendiri dengan Lebih Memahami Virus Corona. Jangan Takut Virus Corona. Jakarta : Rapha Publishing.

Baskoro, L., \& Bayyinah, N. (2020). Penerapan metode design thinking pada mata kuliah desain pengembangan produk pangan. Jurnal IKRA-ITH Humaniora, 4(2), pp. 83-93. https:// journals.upiyai.ac.id/index.php/ ikraithhumaniora/article/view/560.

Batmetan, J. R.(2018). Model Desain Thinking Pada Perancangan Aplikasi Mobile Learning. Telematika, 1(2), pp. 23-30. https://doi.org/10.17605/ OSF.IO /FV2YC

Daalsgard, P. (2014). Pragmatism and Design Thinking. International Journal of Design, 8(1), pp.143-155.

Deuis, N.A., Muhammad, S.A \& Dani, A. (2019). Pengaruh Penggunaan Animasi Terhadap Iklan Produk Richeese Nabati Terhadap Keputusan Pembelian Konsumen. Citisee . 217-223. 
Firmansyah, F. H. and Sari, I. P. (2019). Pengembangan media pembelajaran interaktif berbasis android untuk pembelajaran terbuka dan jarak jauh di Universitas Pendidikan Indonesia. Jurnal Pendidikan Multimedia, 1(2), pp. 99-108. https://doi. org/10.17509/ edsence.v1i2.21667

Gunawan, I. (2015). Metode Penelitian Kualitatif: Teori dan Praktik. Jakarta : Bumi Aksara.

Moleong, L. J. (2014). Metode Penelitian Kualitatif. Remaja Rosdakarya.

Moriarty, S. (2011). Advertising (8th ed.). Jakarta : Kencana Publishing.

Plattner, H., (2010). An Introduction to Design Thinking Process Guide, Stanford: Institute of Design at Stanford

Putri, I. G. A. V. W. (2020). Semiotika tanda verbal dan visual pada iklan kampanye pencegahan penyebaran COVID-19. Kulturistik: Jurnal Bahasa Dan Budaya, 4(2), pp. 10-18. https:// doi.org/10.22225/kulturistik.4.2.1871

Razi, A.A., Intan, R.M., Pindi, S. (2018). Penerapan metode design thinking pada model perancangan UI/UX Aplikasi penanganan laporan kehilangan dan temuan barang tercecer. Jurnal Desain Komunikasi Visual, Manajemen Desain dan Periklanan, 3(2), pp. 75-93. https://doi.org/10.25124/demandia.v3io2.1549

Razzouk, Rim, \& Shute, Valerie. (2012). What Is Design Thinking and Why Is It Important?. AERA, 1(3), pp. 337. https://doi. org/10.3102/0034654312457429.

Saputra, T.A. (2016). Implementasi Design Thinking dalam Membangun Inovasi Model Bisnis Perusahaan Percetakan. Jurnal Agora. 4(1), pp. 833844

Schallmo, D., C.A. Williams \& Katharina,
E.K. (2020). Applying Design Thinking During the COVID-19 Pandemic in Higher Education. Proceedings: LUT Scientific and Expertise Publications. Avaible at https://www.researchgate. net/publication/346534632/

Sugiyono. (2014). Memahami Penelitian Kualitatif. Surabaya : Alfabeta.

Sunarya, A., Bayu, P.Y \& Andi, N. (2015). Membangun Media Promosi dengan Karakter Animasi 3D. Jurnal ICIT, 1(1), pp. 26-38.

Suryadi, E. (2018). Strategi Komunikasi: Sebuah Analisis Teori dan Praktis di Era Global. Remaja Rosdakarya.

Sutrisno, Yuningsih, N., \& Agustino, L. (2018). Komparasi Teori Marketing Politik 4p Menurut Niffeneger dan 3p Menurut Adman Nursal. Jurnal Ilmu Pemerintahan Dan Sosial Politik Universitas Medan Area, 6(2), pp. 106. https://doi.org/10.31289/jppuma. v6i2.1617.

Tohiroh, N. (2021). Implementasi Informasi Mengenai Covid-19 Pada Web Iklan Berbasis Mobile. Jurnal Ilmiah Teknologi Sistem Informasi. 2(3), pp. 69-70.

Ulum, S., Endang, S dan T. Listriyono. (2021). Iklan Layanan Masyarakat Bertahan Melawan Pandemi Covid-19. Jurnal Dialektika Informatika (Detika). 1 (2), pp. 32-37

Vianna, M. (2011). Business Innovation Design Thinking. Rio De Jeneiro : MJV Press.

Wibowo, Ridwan, M., \& Setiaji, H. (2020). Perancangan Website Bisnis Thrifdoor Menggunakan Metode Pendekatan Design Thinking. Automata, 1(2), pp. 15.https://journal.uii.ac.id/AUTOMATA/article/view/15408. 